\title{
PERIOD BATCH CONTROL - A PRODUCTION PLANNING SYSTEM APPLIED TO VIRTUAL MANUFACTURING CELLS
}

\author{
Tesic, Z.; Stevanov, B. ; Jovanovic, V. ${ }^{* *}$; Tomic, M.* \& Kafol, C. ${ }^{* * *}$ \\ *Department of Industrial Engineering and Management, Faculty of Technical Sciences, \\ University of Novi Sad, Trg Dositeja Obradovića 6, 21000 Novi Sad, Serbia \\ ${ }^{* *}$ Department of Engineering Technology, Frank Batten College of Engineering and Technology, \\ Old Dominion University; 111-D Kaufman Hall, Norfolk, VA 23529, USA \\ ${ }^{* * *}$ Informatika d.d., Vetrinjska 2, SI-2000 Maribor, Slovenia \\ E-Mail: ztesic@uns.ac.rs, branisha@uns.ac.rs, v2jovano@odu.edu, milostomic2@gmail.com, \\ ciril.kafol@informatika.si
}

\begin{abstract}
Period Batch Control (PBC) system has been known for its implementation with the classical group technology (GT) cells, and it has been known for its simplicity. The main production planning decisions concern the choice of the period length and the stage number and contents. Also, in order to better integrate the production planning with the application of GT cells at the shop floor, the concept of virtual manufacturing cells has been applied. Since virtual cells configurations are changing periodically, a model for implementing the PBC system into virtual manufacturing cells environment is developed. The model enables alignment of the PBC principles and rules with virtual cell design goals. Model is tested on the case study of furniture production. With the use of scheduling software, different scheduling rules were simulated for four production weeks. The experimental results from these for production weeks show how the choice of PBC parameters impacts the virtual cells configurations, machine sharing and utilization.

(Received in July 2015, accepted in December 2015. This paper was with the authors 1 month for 1 revision.)
\end{abstract}

Key Words: Period Batch Control, Virtual Cell, Schedule Simulation

\section{INTRODUCTION}

The need for increasing market competitiveness, in terms of responding to the changing customer demands and to the increase of work productivity and product quality, has influenced the organization of today's production systems. Production companies produce a high number of final product variants in order to stay competitive on the market. The production systems need to be flexible and to provide products in reasonable time. On the other hand, production processes can be complex, which affects manufacturing throughput time. One way to organize the production system to be competitive is through the application of group technology (GT). Implementation of GT principles and methods is often connected to the physical reorganization of the shop floor layout, by grouping the machines and other resources into cells. It is interesting to notice that sometimes the physical reorganization at the shop floor is not feasible, for example because of the high costs of the reorganization of shop floor layout. In such cases another form of GT cells can be used, and that are the virtual manufacturing cells. When using the virtual manufacturing cells, there is no physical moving of the machines at the shop floor, the grouping is only virtual (logical) [1]. Logical organization means that virtual cells exist only within the production planning and control function [2]. The successful application of group technology also depends on the choice of production planning system. The reorganization of the production system requires changes in production planning and in the approach of how the created production plans are implemented at the shop floor. Also production can be better planned if simulation is used in the planning process [3], especially in job scheduling [4] and testing of the future behaviour of the production system [5]. The production planning system that showed to be good to combine 
with the group technology is the Period Batch Control (PBC) system [6]. When designing the PBC system it is important to define the parameters of period length and stage number and contents, since they influence the total throughput time for customer orders. In order to achieve the flexibility of virtual cells and the simplicity of production planning process offered by PBC system, we propose a method for production planning of the virtual cells at the shop floor. The method takes into consideration the dynamic structure of virtual cells and the best practices of the PBC system. The paper presents a method for the planning process, concerning the creation of the virtual cells at the shop floor, the definition of the PBC parameters, and the reconfiguration of the virtual cells as the result of checking the conditions for the period length (within the analysis of the machine workload and the simulation of production schedule).

\section{LITERATURE REVIEW}

\subsection{Virtual manufacturing cells}

Virtual manufacturing cell can be defined as the application of group technology in the production system where machines remain at their physical positions, and the cell exists only within the production planning and control system [7]. Virtual cell configurations can exist on the master production schedule (MPS) level, on the MRP level and on the shop floor control (SFC) level [8]. Dependent on which production planning level the virtual cell belongs, its existing configuration can last for a longer or shorter time period.

The production planning of virtual manufacturing cells includes different design objectives concerning the material flows, the resource utilization and sharing, and the production costs. Also, due to changes in products mix, changes in production technology and changes in products materials and structure, the virtual cell configuration can change periodically. Balakrishnan and Cheng investigate a multi-period production planning for the cellular manufacturing and state that the products life cycle is shortening and that products change faster, which eventually results with changes in the cell configuration [9]. They propose different layout solutions for GT cells reconfiguration and one of them are virtual cells. Nomden et al. identify that one of the future research directions in virtual cellular manufacturing could be the testing of design methods for periodical forming of virtual cells [2]. Periodical design of the virtual cells has been a research subject published in several research papers $[8,10-14]$.

\subsection{Period Batch Control}

PBC system uses the idea that the production process is performed through production stages with fixed time period lengths [6]. Parts wait in buffers between successive production stages. In the PBC system the manufacturing throughput time $T$ is defined as the product of the number of production stages $N$ and the length of the planning period $P$ [6]. Production processes within the stages function through the GT cells. The PBC system was created by Gigley in the period between the two world wars, and after the World War II the development had been done by Burbidge [15]. Application of the PBC system is reported in many papers, covering many industries such as the implosive industries (foundries, glass works, potteries etc.) [16], newspaper production [17], furniture production [6], shoes production [18] and capital goods production [19] among others.

The characteristic of the PBC system is that production orders are launched at the same time (the beginning of the period) and that they also have the same due dates (the end of the period) [20]. If all the products and its subassemblies and its parts, have the same number of production phases and same delivery cycles, then this PBC system can be characterized as an 
unicycle PBC system [20]. The most important planning decision in PBC system is the period length determination. It is discussed in several papers [20-23]. The second important planning decision concerns the production stages definition. The number of production stages and its contents are dependant of factors such as setup time's lengths, period length and the results of material flow analysis. The length of the planning period can influence the number of production stages and the number of production operations which are possible to perform in the single production stage. Period length also influences the setup times for machines within a production stage, such that larger period length causes smaller setup time costs [20]. When defining the stage contents, it is necessary to analyse the material flows and to combine machines which complete the set of operations for parts or products [24].

$\mathrm{PBC}$ approach to production planning is different from other planning approaches since it focuses more on time factor (period length) than on some other factor which influences manufacturing lead time, like the batch size for instance which is seen in [25]. Having in sight the PBC system, which is on the same level as the MRP system in the production planning and control hierarchy, it would be interesting to investigate the periodical planning of virtual manufacturing cells with the PBC principles and rules applied. Important issue to cover is how to align the design goals for virtual cells on one side, and the choice of the PBC parameters (period length and stage number and contents) on the other side.

\section{METHOD FOR PLANNING OF VIRTUAL CELLS}

From the literature review it is concluded that the PBC system and its design parameters were widely described and explained. Also in many research papers the periodical nature of creating and changing the virtual manufacturing cells is mentioned. The basic idea of the PBC system with virtual cells is given in Fig. 1. The proposed model for the production planning of virtual cells is given in the form of algorithm, which is presented in Fig. 2. Design objectives for virtual cells and PBC system are:

- Increase of parts similarity coefficient.

- Reduction of number of created virtual cells.

- Reduction of distance that material needs to pass between machines which create virtual cell.

- Reduction of cell overlapping.

- Reduction of length of the period $P$ which allows the part groups production.

- Reduction of number of the production stages in order to shorten customer order throughput time.

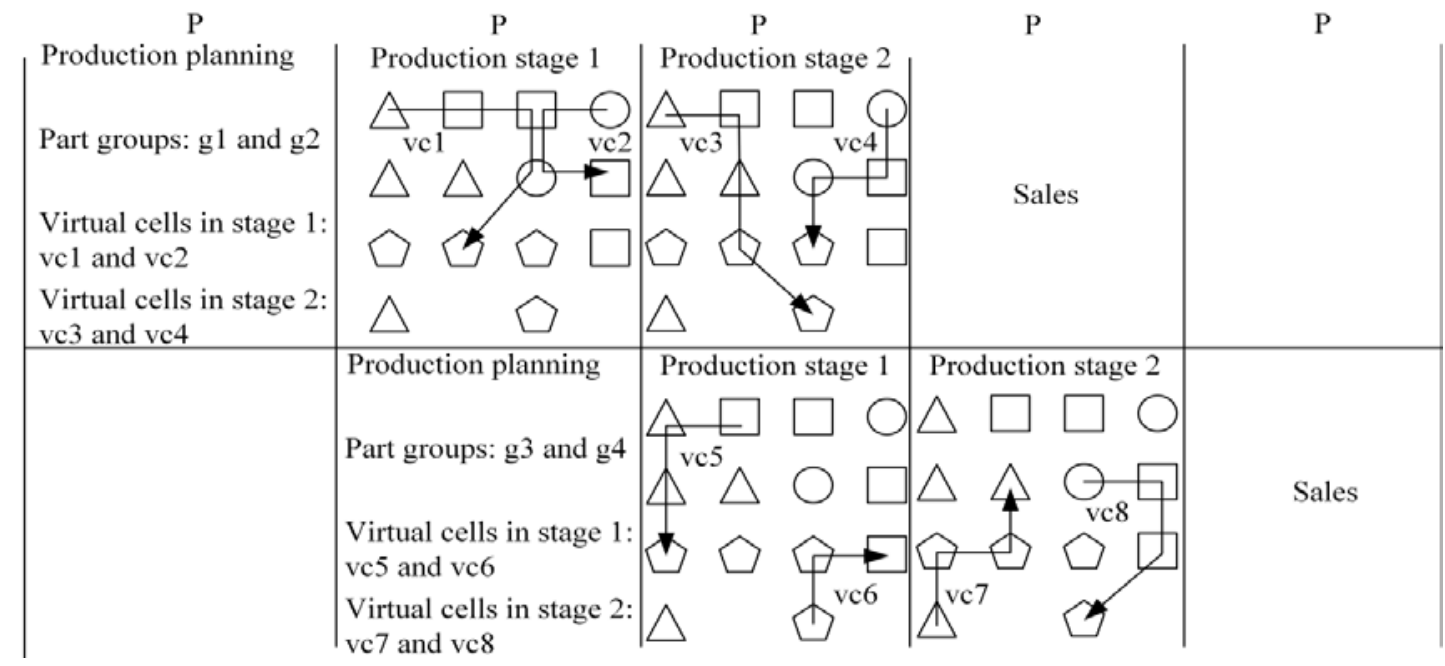

Figure 1: Virtual manufacturing cells and PBC system. 


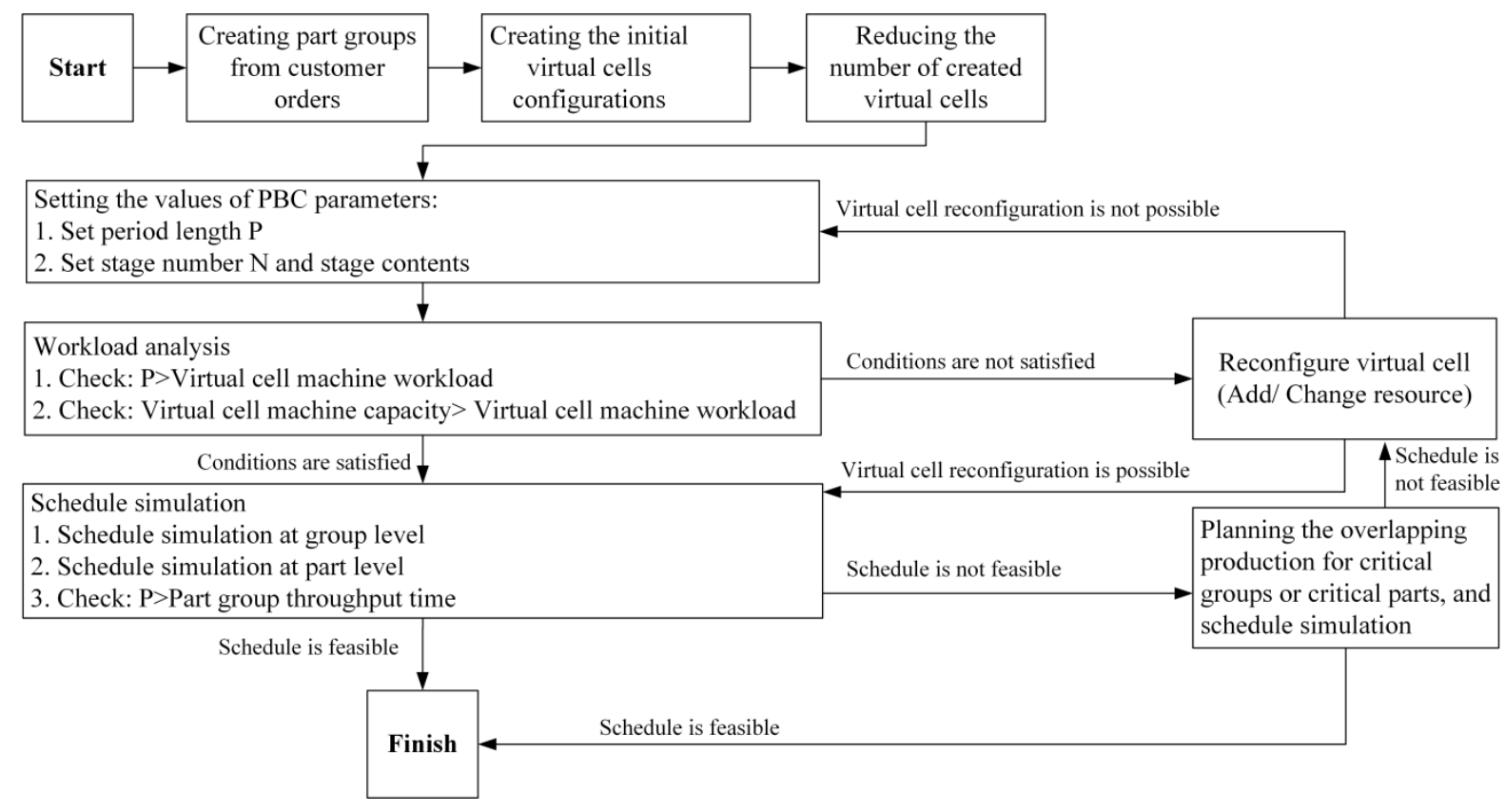

Figure 2: Algorithm for production planning of virtual cells.

Algorithm steps are explained below.

\subsection{Creating part groups from customer orders}

The customer orders are accepted within the period $P$. Product parts list and quantities are obtained by using bill of materials explosion. Forming of parts group is done by the similarity of production process steps. The calculation of the parts similarity coefficient is done by a mathematical formula shown in [26]:

Variables definition:

$$
S_{K L}^{P}=\frac{N_{K L}^{M}}{N_{K K}^{M}+N_{L L}^{M}+N_{K L}^{M}}
$$

- $S_{K L}^{P} \quad$ - similarity coefficient for parts $K$ and $L$,

- $N^{M}{ }_{K L}$ - number of machines used by both parts $K$ and $L$,

- $N_{K K}^{M}$ - number of machines used by part $K$,

- $N^{M}{ }_{L L}$ - number of machines used by part $L$.

Similarity coefficients represent numbers between 0 and 1 and are used in the parts similarity matrix for forming parts groups. Two parts are more similar if their similarity coefficient is closer to number 1 .

\subsection{Creating the initial virtual cells configurations}

For created part groups the initial virtual cells need to be formed. For every part group it is important to select a group of machines that will satisfy the part group production steps (operations). For every part group there is one initial virtual cell created, as shown in Fig. 1, where for every part group exists one virtual cell in each production stage. For the formation of virtual cells, the graph theory approach is used. The production system is presented as graph $G(V, E)$ where the $V$ presents set of vertices (machines on the shop floor), and the $E$ presents set of edges which connect these vertices. Every edge has an attribute that presents the physical distance between the two machines. To create virtual cells the Dijkstra algorithm [27] is used. With this algorithm the shortest route in a graph is searched (with respecting the constraint for part groups' production steps). Algorithm application provides virtual cell 
formation with the minimization of material flow between machines. Every created virtual cell represents a sub-graph of graph $G$.

Initial virtual cells configurations are created with the use of NetworkX ${ }^{\circledR}$ graph programming library [28]. The initial configuration of a virtual cell can be changed (reconfigured) depending on:

- The machine capacity load analysis, e.g. if the machines in the virtual cell are overloaded.

- The length of the production cycle, e.g. if the production cycle is too long.

- The length of the period $P$, e.g. if the production cannot be completed in the given period.

\subsection{Reducing the number of created virtual cells}

To simplify the production planning and control process, the number of initially created virtual cells can be reduced. For example, if a certain virtual cell consists of the same or mostly the same set of resources as some other virtual cell, or if the resources of some virtual cell present a subset of the resources of the other virtual cell, then these virtual cells can merge. The virtual cell that resulted from the merging operation then produces all part groups which belonged to the different virtual cells before merging.

\subsection{Setting the values of PBC parameters}

Determination of PBC parameters could be a process that will require several iterations to reach the optimal period length and stage number.

The starting length of the time period can be determined by using the information from the production system (number of work hours, number of work shifts etc.), information about production program and the information from bills of materials as in [21]. In [21], several values are tested in the practice and the period length of one working week has shown to be adequate. The starting length of period $P$ could be set up also before virtual cell formation, since the period length can change due to the current situation in the production system.

The number of production stages can have influence on the scheduling because different stages could overlap during the same period (for example, in Fig. 1, the overlapping occurs between the second production stage for part groups $g 1$ and $g 2$, and the first production stage for part groups $g 3$ and $g 4$ ). The overlapping of stages further affects the overlapping of virtual cells. Contents of the stage include operations that are performed on materials or parts. Contents of the stage influence virtual cell resource occupation within the same period. In [20] the stage number is discussed, concerning the case of the smaller number of stages with longer period length and the case of the larger number of stages with shorter period length. Applied to the virtual cells environment, the first case with smaller number of stages enables receiving customer orders of larger quantity, creating virtual cells with larger number of machines and having larger job overlapping between virtual cells in a stage. The second case with larger number of stages enables smaller number of machines per virtual cell, which facilitates the scheduling within the stage. Existence of the virtual cell is restricted to the production stage.

\subsection{Workload analysis}

Two conditions have to be satisfied here. The first condition is that the time length of the period has to be bigger than the time that represents the load of the virtual cell machine for production of different part groups in a production stage, as shown in formula below:

Variables definition:

$$
P \geq \sum_{g=1}^{m}\left(\sum_{j=1}^{k_{g}} n^{j} t_{i i}^{j}+\sum_{j=1}^{k_{g}} t_{s}^{j}\right)
$$

- $P$ - period length, 
- $g$ - index of the part group,

- $m$ - number of part groups,

- $j$ - index of the part type that belongs to the part group $g$,

- $k_{g}$ - number of different part types that belong to the part group $g$,

- $n-$ number of units of part type $j$,

- $t^{j}{ }_{i i}$ - production time for a single unit of part type $j$,

- $t^{j}{ }_{s}$ - setup time for the batch of parts of type $j$.

Second condition concerns the available capacity of virtual cell machines against the workload demands. If the part groups can be produced at the virtual cell machines within a period length, then there is no need for including additional machines, or for changing the bottleneck machine for some alternative machine with bigger available capacity. Inclusion of the additional machines into the virtual cell can shorten the processing or assembly time and increase the machining capacities, but also can increase the setup time. If virtual cells cannot be reconfigured, the PBC parameters should be revised, for example the period length could be increased.

\subsection{Schedule simulation}

When making the production schedule it is important to have in mind that in the PBC system the work orders are released at the same time moment $[20,29]$. The work order is tied to the part group which is produced in a production stage. The main idea is that the virtual cell exists only within a stage and the current configuration lasts as long as is the length of the period $P$. After the production in some stage is finished, same machines can form another virtual cell for the next period.

Scheduling exists on two levels, at group level and at parts level. Scheduling is done by using the appropriate rules or scheduling heuristics. The criterion is to shorten throughput time for part groups. The time length of the period $P$ needs to be bigger than the throughput time needed for the part group production in the virtual cell in the certain stage. Different scheduling rules can be simulated through scheduling software, as shown in [30]. The combination of scheduling rules and heuristics on both levels which best fits the given criterion is used. For example, the longest processing time rule (LPT) can be used to determine the processing or assembly order of part groups, and then within a certain part group, the shortest processing time rule (SPT) can be used to determine the processing or assembly order of parts. Certain scheduling rules like the earliest due date rule (EDD) and first come first serve rule (FCFS) are not taken into consideration because of the nature of the PBC system. The EDD rule is not being considered since the part groups have the same due date which is the period length $P$, and FCFS rule is not being considered because work orders in the PBC system are launched at the same time.

Resource sharing can exist between the virtual cells in the same processing stage, for example, in Fig. 1, virtual cells $v c 1$ and $v c 2$ share some machines within the same stage. If there are more production stages which overlap within the same period, then the scheduling includes resource sharing between the virtual cells from different production stages (for example, in Fig. 1, virtual cells $v c 3$ and $v c 5$ share two machines, virtual cells $v c 4$ and $v c 6$ share one machine and virtual cells $v c 3$ and $v c 6$ also share one machine). If the schedule is not feasible, then the throughput time for critical part group can be shortened if overlapping production is used. The overlapping production can be used for all the parts from the part group, or just for the parts that demand long production times or have large quantity of units to be produced. Overlapping production introduces sub-batches into the shop floor and for the part group can increase the complexity of material flows in the production system. The time needed for the production of sub-batches depends on the number of sub-batches, on the 
number of machines of the same type that are available, sub-batch part quantities, parts production and setup times and transfer times between machines. All sub-batches are needed to be included into schedule simulation. After the scheduling is finished, the production of part the groups can start.

Period length should be revised occasionally, for example in a case when in several successive periods production is finished before period expires or in another case when in several successive periods production cannot be finished before period expires. In such cases the period length could be revised.

\section{CASE STUDY}

Research was done in a furniture production company from Serbia. The company makes all sorts of furniture for living rooms, kitchens, bathrooms, bedrooms, gardens and backyards. The machine layout at the shop floor is presented in Fig. 3. Shop floor machines can do operations of cutting (machines 1a and $1 \mathrm{~b}$ ), one-side machining of edges (machine $2 \mathrm{a}$ ), twoside machining of edges (machines $3 \mathrm{a}, 4 \mathrm{a}, 5 \mathrm{a}, 5 \mathrm{~b}, 5 \mathrm{c}$ ) and drilling (machines $6 \mathrm{a}, 7 \mathrm{a}, 8 \mathrm{a}, 8 \mathrm{~b}$, $8 \mathrm{c})$. There are also two CNC machining centres, labelled $9 \mathrm{a}$ and $10 \mathrm{a}$, for the more complex parts processing. The processing of parts is done in one stage. Processed parts then go to control, and after that to packaging. Finished parts are packed in the warehouse and shipped to the customers' location, where they are assembled into final product. If necessary, for certain processing operations, the machine or the machining centre can aid the overloaded machines. For example, the machining centre 9a can aid the machines $6 \mathrm{a}, 7 \mathrm{a}$ or $8 \mathrm{a}$ (the processing time depends on the part type). The machine distance matrix is given in Table I. The experimental research is done for four weeks on the same production system, with the changes in products mix and in quantities for each week. Starting period length is the one week. The algorithm steps are only shown for the first production week, since the length of the paper would substantially increase if all for week experiments were shown step by step.

\subsection{Production planning of virtual cells in the first week}

It is already shown in [31] that GT principles can successfully be applied to furniture production.

By using the products bills of materials, part quantities are calculated from customer orders. Part quantities for weekly production and processing times are shown in Table II. Criterion for the parts grouping is that theirs similarity coefficient is minimum 0.6. If the part did not fit into any group, as for example part p16, then that part is moved to the group where similarity coefficient between that part and the parts from the chosen group has the highest value (in case of part p16 that is part group $g 2$ ). Six part groups are created:

- Part group g1 with parts p13, p14, p15, p17, p22, p23, p24 and p26.

- Part group g2 with parts p1, p5 and p16.

- Part group g3 with parts p2, p6, p7, p27, p28, p29 and p30.

- Part group g4 with parts p3, p9, p10, p18 and p19.

- Part group g5 with parts p8, p11, p12, p20 and p21.

- Part group g6 with parts p4 and p25.

A graph is formed representing existing machines as nodes, which are connected with edges whose weights are distances between these machines. For every part group the virtual cell is identified by applying Dijsktra [27] algorithm and with respect to the machines which are needed for parts group production:

- Virtual cell $v c-1$ with machines $1 \mathrm{~b}, 2 \mathrm{a}, 5 \mathrm{a}, 8 \mathrm{a}$ (for production of part group $g 1$ ).

- Virtual cell $v c-2$ with machines 1 b, 5a (for production of part group g2). 
- Virtual cell $v c-3$ with machines 1a, 3a, 4a, 6a (for production of part group g3).

- Virtual cell $v c-4$ with machines $1 \mathrm{~b}, 3 \mathrm{a}, 5 \mathrm{a}, 7 \mathrm{a}$ (for production of part group g4).

- Virtual cell $v c-5$ with machines 1a, 2a, 4a, 6a (for production of part group g5).

- Virtual cell $v c-6$ with machines 1a (for production of part group g6).

The number of virtual cells can reduce since some part groups use the same or almost the same set of machines in a processing stage. Virtual cell $v c-2$ consists of a machine set which is a subset of machines set of virtual cell $v c-1$, and so they form one virtual cell labelled $v c$ 12. Virtual cells $v c-3, v c-5$ and $v c-6$ also merge into one cell labelled $v c-356$. The number of existing virtual cells is reduced from 6 to 3 :

- Virtual cell $v c-12$ with machines $1 \mathrm{~b}, 2 \mathrm{a}, 5 \mathrm{a}, 8 \mathrm{a}$ (for production of part groups $g 1$ and g2).

- Virtual cell $v c-\underline{4}$ with machines $1 \mathrm{~b}, 3 \mathrm{a}, 5 \mathrm{a}, 7 \mathrm{a}$ (for production of part group $g 4$ ).

- Virtual cell $v c-356$ with machines $1 \mathrm{a}, 2 \mathrm{a}, 3 \mathrm{a}, 4 \mathrm{a}, 6 \mathrm{a}, 7 \mathrm{a}$ (for production of part groups $g 3, g 5$ and $g 6$ ).

Machine sharing exists between virtual cells:

- Virtual cells $v c-12$ and $v c-4$ share machines $1 \mathrm{~b}$ and $5 \mathrm{a}$.

- Virtual cells $v c-12$ and $v c-356$ share machine $2 \mathrm{a}$.

- Virtual cells $v c-4$ and $v c-356$ share machine $3 a$.

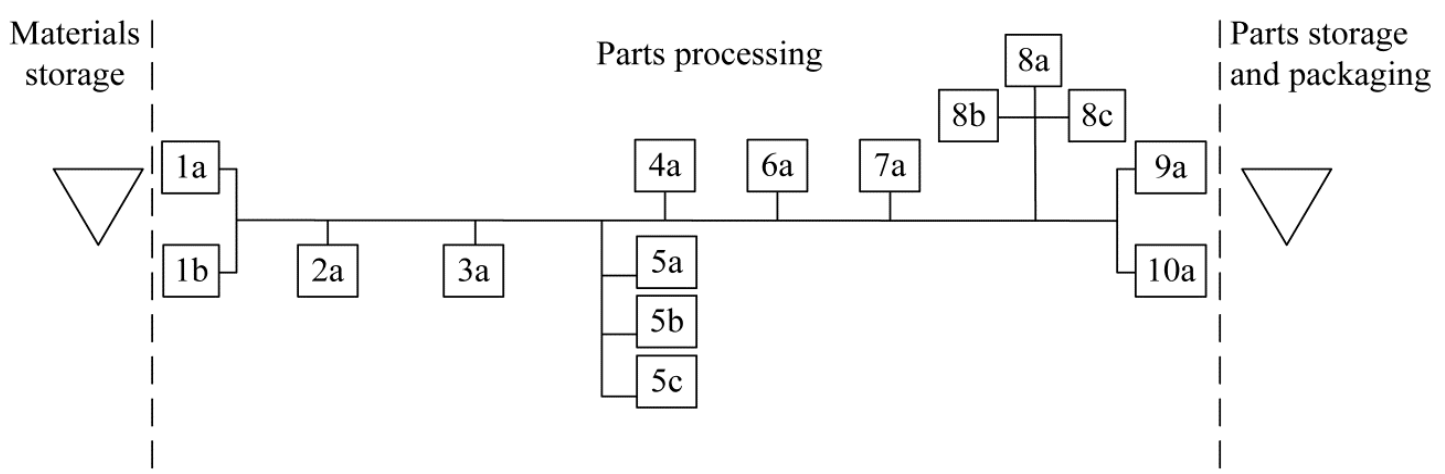

Figure 3: Shop floor layout.

Table I: Machine distances [metres].

\begin{tabular}{|c|c|c|c|c|c|c|c|c|c|c|c|c|c|c|c|}
\hline Machine & $\mathbf{1 a}$ & $\mathbf{1 b}$ & $\mathbf{2 a}$ & $\mathbf{3 a}$ & $\mathbf{4 a}$ & $\mathbf{5 a}$ & $\mathbf{5 b}$ & $\mathbf{5 c}$ & $\mathbf{6 a}$ & $\mathbf{7 a}$ & $\mathbf{8 a}$ & $\mathbf{8 b}$ & $\mathbf{8 c}$ & $\mathbf{9 a}$ & $\mathbf{1 0 a}$ \\
\hline $\mathbf{1 a}$ & - & 3 & 12 & 44 & 44 & 58 & 61 & 64 & 65 & 72 & 84 & 84 & 84 & 82 & 82 \\
\hline $\mathbf{1 b}$ & & - & 12 & 44 & 44 & 58 & 61 & 64 & 65 & 72 & 84 & 84 & 84 & 82 & 82 \\
\hline $\mathbf{2 a}$ & & & - & 33 & 33 & 47 & 50 & 53 & 54 & 61 & 73 & 73 & 73 & 71 & 71 \\
\hline $\mathbf{3 a}$ & & & & - & 3 & 14 & 17 & 20 & 21 & 28 & 40 & 40 & 40 & 38 & 38 \\
\hline $\mathbf{4 a}$ & & & & & - & 14 & 17 & 20 & 21 & 28 & 40 & 40 & 40 & 38 & 38 \\
\hline $\mathbf{5 a}$ & & & & & & - & 3 & 6 & 7 & 14 & 26 & 26 & 26 & 23 & 23 \\
\hline $\mathbf{5 b}$ & & & & & & & - & 3 & 10 & 17 & 29 & 29 & 29 & 26 & 26 \\
\hline $\mathbf{5 c}$ & & & & & & & & - & 13 & 20 & 32 & 32 & 32 & 29 & 29 \\
\hline $\mathbf{6 a}$ & & & & & & & & & - & 7 & 19 & 19 & 19 & 16 & 16 \\
\hline $\mathbf{7 a}$ & & & & & & & & & & - & 12 & 12 & 12 & 9 & 9 \\
\hline $\mathbf{8 a}$ & & & & & & & & & & & - & 3 & 3 & 16 & 16 \\
\hline $\mathbf{8 b}$ & & & & & & & & & & & & - & 3 & 16 & 16 \\
\hline $\mathbf{8 c}$ & & & & & & & & & & & & & - & 16 & 16 \\
\hline $\mathbf{9 a}$ & & & & & & & & & & & & & & - & 3 \\
\hline $\mathbf{1 0 a}$ & & & & & & & & & & & & & & & - \\
\hline
\end{tabular}


Tesic, Stevanov, Jovanovic, Tomic, Kafol: Period Batch Control - A Production Planning ...

Table II: Processing times for parts [seconds] and parts weekly demand.

\begin{tabular}{|c|c|c|c|c|c|c|c|c|c|c|}
\hline \multirow{2}{*}{ Parts } & \multicolumn{9}{|c|}{ Machines } & \multirow{2}{*}{ Demand } \\
\hline & $1 \mathrm{a}$ & $1 \mathrm{~b}$ & $2 a$ & $\mathbf{3 a}$ & $4 \mathbf{a}$ & $5 a$ & $6 a$ & $7 a$ & $8 \mathbf{a}$ & \\
\hline p1 & & 7 & & & & 14 & & & & 2632 \\
\hline p2 & 11 & & & 11 & & & 43 & & & 457 \\
\hline p3 & & 8 & & 9 & & & 35 & & & 203 \\
\hline p4 & 11 & & & & & & & & & 1378 \\
\hline p5 & & 8 & & & & 17 & & & & 203 \\
\hline p6 & 11 & & & 12 & & & 22 & & & 636 \\
\hline p7 & 11 & & & 12 & & & 23 & & & 636 \\
\hline p8 & 11 & & 26 & & 10 & & 20 & & & 338 \\
\hline p9 & & 7 & & 7 & & 14 & & 10 & & 195 \\
\hline p10 & & 7 & & 6 & & 14 & & 12 & & 195 \\
\hline p11 & 11 & & 26 & & 10 & & 20 & & & 367 \\
\hline p12 & 9 & & 22 & & 10 & & 20 & & & 225 \\
\hline p13 & & 6 & & & & 12 & & & 66 & 2025 \\
\hline p14 & & 7 & & & & 17 & & & 60 & 4050 \\
\hline p15 & & 6 & & & & 12 & & & 30 & 2025 \\
\hline p16 & & 5 & & & & & & & & 2025 \\
\hline p17 & & 7 & 9 & & & 28 & & & 50 & 2025 \\
\hline p18 & & 8 & & 9 & & 23 & & 20 & & 180 \\
\hline p19 & & 8 & & 9 & & 23 & & 10 & & 180 \\
\hline p20 & 10 & & 22 & & 10 & 14 & 9 & & & 203 \\
\hline p21 & 10 & & 22 & & 10 & 14 & 9 & & & 203 \\
\hline p22 & & 8 & & & & 14 & & & 72 & 812 \\
\hline p23 & & 7 & & & & 20 & & & 60 & 1624 \\
\hline p24 & & 8 & & & & 17 & & & 32 & 812 \\
\hline p25 & 9 & & & & & & & & & 812 \\
\hline p26 & & 8 & 9 & & & 56 & & & 54 & 812 \\
\hline p27 & 10 & & & 11 & 8 & & 23 & & & 221 \\
\hline p28 & 10 & & & 11 & 8 & & 10 & & & 221 \\
\hline p29 & 11 & & & 13 & 8 & & 25 & & & 40 \\
\hline p30 & 11 & & & 12 & 8 & & 13 & & & 40 \\
\hline
\end{tabular}

Table III: Machine workload [minutes].

\begin{tabular}{|c|c|c|c|c|c|c|c|c|}
\hline $\mathbf{1 a}$ & $\mathbf{1 b}$ & $\mathbf{2 a}$ & $\mathbf{3 a}$ & $\mathbf{4 a}$ & $\mathbf{5 a}$ & $\mathbf{6 a}$ & $\mathbf{7 a}$ & $\mathbf{8 a}$ \\
\hline 1015 & 2260 & 966 & 567 & 297 & 5527 & 1327 & 281 & 12743 \\
\hline
\end{tabular}

The starting length of the time period $P$ is one week which corresponds to 4800 minutes (two shifts of eight hour time, during five working days), and the number of processing stages $N$ is one. The workload conditions for the period length are checked. The workload of machines is given in Table III. Data in Table III shows that machines 5a and 8a are overloaded and that the workload on those machines is bigger than the initial period length and the machines available capacities. To solve this problem the additional machines are included into virtual cell $v c-12$. The machines $5 \mathrm{~b}$ and $5 \mathrm{c}$ support the processing demand for machine $5 \mathrm{a}$, and the machines $8 \mathrm{~b}, 8 \mathrm{c}$ and multi-purpose machining centre $9 \mathrm{a}$ support the processing demand for machine $8 \mathrm{a}$. Virtual cell $v c-12$ now has a changed configuration:

- $1 \mathrm{~b}, 2 \mathrm{a}, 5 \mathrm{a}, 5 \mathrm{~b}, 5 \mathrm{c}, 8 \mathrm{a}, 8 \mathrm{~b}, 8 \mathrm{c}, 9 \mathrm{a}$.

In this reconfigured virtual cell only the parts from group $g 1$ are processed with the use of added machines, because of the higher part volume demand. Processing times for the parts from the part group $g 1$ on the machining centre $9 \mathrm{a}$ is larger than on machines $8 \mathrm{a}, 8 \mathrm{~b}$ and $8 \mathrm{c}$. 
Scheduling simulation was done using the Microsoft Excel ${ }^{\circledR}$ software and the educational edition of the LEKIN ${ }^{\circledR}$ software [32]. The priority rules taken into consideration were LPT, SPT, Critical Ratio (CR), Minimum Slack (MS), and Shifting Bottleneck heuristic (SB) with objectives such as the minimization of the makespan (Cmax) and minimization of tardiness (Tmax). Throughput times for the part groups are presented in Table IV. All part groups for the first production week are produced within the period length. The best result in respect to the period length $P$ gave the use of LPT rule at the group level, which was combined with the several different rules and heuristics on the parts level (SB / Tmax heustistics for part groups $g 1, g 2$ and $g 4$, SB /Cmax heustistics for part group $g 3$, LPT rule for part group $g 5$ and SPT rule for part group $g 6$ ).

Table IV: Part groups throughput times as a result of the schedule simulation [minutes].

\begin{tabular}{|l|c|c|c|c|c|c|}
\hline Virtual cell & \multicolumn{2}{|c|}{$v c-12$} & $v c-4$ & \multicolumn{3}{c|}{$v c-356$} \\
\hline Part group & $g 1$ & $g 2$ & $g 4$ & $g 3$ & $g 5$ & $g 6$ \\
\hline Throughput time & 3500 & 2584 & 2844 & 1064 & 1437 & 1015 \\
\hline
\end{tabular}

The results data for all four production weeks' experiments are discussed in the next section.

\section{RESULTS}

Research results are summarized in tables V, VI and VII. Conducted research uses machines as the resource in forming virtual cells. Only in the first week experiment all jobs are finished day earlier so the remaining working day of the week can be used for doing for example the cooperative work for a business partner. For the third week experiment, the overlapping production had to be used because the length of the period would not suffice for the processing of parts. Virtual cell machine capacity utilization is analysed before the production starts, within checking the conditions for period length. Scheduling is done in a way that all part groups are scheduled to virtual cells, within a production stage of given period length. Work order ties to the part group and the virtual cell configuration lasts as long as is the length of the period. The proposed capacity analysis and scheduling is different from the opportunistic scheduling proposed in [10], where every job is scheduled separately to virtual cell, according to a previously created priority list. In [10] virtual cells are created during the opportunistic scheduling and the machines capacities utilization updates after job is scheduled.

Schedule simulation has shown, as seen in Table V, that at group level the most dominant scheduling rule for all four week experiments was LPT (used in three of four weeks), and at parts level it was the SPT scheduling rule (used on 14 part groups) followed by SB / Tmax heuristic (used on 10 part groups). Within every of the four testing weeks the production of the parts was done within the defined planning period. The longest throughput time in all four experiments was 4108 minutes. The length of the planning period can shorten by the one eight-hour shift. The length of the period $P$ can adjust to 4320 minutes, which is still oneweek period but with one work shift less on the last working day. The experimental results show that the production system is flexible, due to the changes in part quantities and the changes in customer demands for different products. The decrease of the system flexibility to changes in the products mix and quantities, due to the period length shortening which is noted in [20], can ease with virtual cells application.

The results shown in Table VI indicate that the machine capacity utilization is not balanced and some machines are not used in every week. There is a need for optimization of machine usage and the extension of the algorithm shown on Fig. 2 is suggested as a future 
work. Virtual cell formation decisions need to include this additional design objective, which increases the complexity of the production planning process.

Table V: Results of production planning and schedule simulation per period (production week).

\begin{tabular}{|c|c|c|c|c|c|c|}
\hline Week & $\begin{array}{l}\text { Number of } \\
\text { different part } \\
\text { types to be } \\
\text { processed }\end{array}$ & $\begin{array}{l}\text { Number of } \\
\text { created } \\
\text { part } \\
\text { groups }\end{array}$ & $\begin{array}{l}\text { Number of } \\
\text { created } \\
\text { virtual } \\
\text { cells } \\
\end{array}$ & \begin{tabular}{|l|} 
Scheduling \\
heuristics or \\
rule on \\
group level $^{++}$ \\
\end{tabular} & $\begin{array}{l}\text { Scheduling heuristics } \\
\text { or rule rules on parts } \\
\text { level }\end{array}$ & $\begin{array}{l}\text { Longest } \\
\text { throughput time } \\
\text { for part groups } \\
\text { [minutes] }\end{array}$ \\
\hline 1 & 30 & 6 & 3 & LPT & $\begin{array}{l}\text { SB / Tmax ( } 3 \text { groups), } \\
\text { SB / Cmax (1 group), } \\
\text { LPT (1 group), } \\
\text { SPT (1 group) }\end{array}$ & 3500 \\
\hline 2 & 89 & 11 & 7 & $\mathrm{SB} / \operatorname{Tmax}$ & $\begin{array}{l}\text { SB /Cmax (1 group), } \\
\text { SB / Tmax (4 groups), } \\
\text { LPT (1 group), } \\
\text { MS (1 group), } \\
\text { SPT (4 groups) }\end{array}$ & 4039 \\
\hline 3 & 59 & 7 & 4 & $\begin{array}{c}\text { MS or CR or } \\
\text { LPT }\end{array}$ & $\begin{array}{l}\text { SB / Cmax (2 groups), } \\
\text { SB / Tmax (2 groups), } \\
\text { SPT (3 groups) }\end{array}$ & 4099 \\
\hline 4 & 112 & 10 & 6 & LPT & $\begin{array}{l}\text { SB / Tmax (1 group), } \\
\text { LPT ( } 3 \text { groups), } \\
\text { SPT (6 groups) }\end{array}$ & 4108 \\
\hline
\end{tabular}

If there is more than one scheduling rule or scheduling heuristics it means that they give the same best schedule order (with same minimum throughput time) on the group level.

Table VI: Machine utilization during the period length [\%].

\begin{tabular}{|c|c|c|c|c|c|c|c|c|c|c|c|c|c|c|c|}
\hline \multirow{2}{*}{ Week } & \multicolumn{10}{|c|}{ Machines } \\
\cline { 2 - 18 } & $1 \mathrm{a}$ & $1 \mathrm{~b}$ & $2 \mathrm{a}$ & $3 \mathrm{a}$ & $4 \mathrm{a}$ & $5 \mathrm{a}$ & $5 \mathrm{~b}$ & $5 \mathrm{c}$ & $6 \mathrm{a}$ & $7 \mathrm{a}$ & $8 \mathrm{a}$ & $8 \mathrm{~b}$ & $8 \mathrm{c}$ & $9 \mathrm{a}$ & $10 \mathrm{a}$ \\
\hline 1 & 29 & 64 & 28 & 16 & 8 & 59 & 33 & 33 & 38 & 8 & 91 & 91 & 91 & 99 & - \\
\hline 2 & 84 & 81 & 83 & 35 & 21 & 81 & 45 & - & 46 & 20 & 80 & 54 & - & 9 & 17 \\
\hline 3 & 40 & 94 & 65 & 45 & 41 & 87 & - & - & 97 & 45 & 86 & - & - & - & 3 \\
\hline 4 & 90 & 98 & 52 & 54 & 24 & 54 & 52 & - & 27 & 64 & 86 & 63 & - & 17 & 11 \\
\hline $\begin{array}{c}\text { Average machine } \\
\text { utilization for all } \\
\text { weeks }\end{array}$ & 61 & 84 & 57 & 38 & 24 & 70 & 33 & 8 & 52 & 34 & 86 & 52 & 23 & 31 & 8 \\
\hline
\end{tabular}

Table VII: The number of virtual cells that share the machine during the period length.

\begin{tabular}{|c|c|c|c|c|c|c|c|c|c|c|c|c|c|c|c|}
\hline \multirow{2}{*}{ Week } & \multicolumn{15}{|c|}{ Machines } \\
\hline & $1 \mathrm{a}$ & $1 \mathrm{~b}$ & $2 a$ & $3 a$ & $4 a$ & $5 a$ & $5 b$ & $5 c$ & $6 a$ & $7 a$ & $8 \mathrm{a}$ & $8 \mathrm{~b}$ & $8 \mathrm{c}$ & $9 a$ & $10 \mathrm{a}$ \\
\hline 1 & 1 & 2 & 2 & 2 & 1 & 2 & 1 & 1 & 1 & 1 & 1 & 1 & 1 & 1 & - \\
\hline 2 & 4 & 3 & 3 & 4 & 2 & 2 & 2 & - & 1 & 1 & 3 & 3 & - & 1 & 3 \\
\hline 3 & 3 & 2 & 1 & 4 & 3 & 2 & - & - & 1 & 2 & 2 & - & - & - & 1 \\
\hline 4 & 3 & 5 & 3 & 4 & 3 & 2 & 1 & - & 1 & 2 & 2 & 1 & - & 1 & 1 \\
\hline
\end{tabular}

The virtual cell machine sharing (shown in Table VII) depends on the sequence of the production operations needed for the parts processing. For example, all the parts are needed to be cut first, so the biggest machine sharing between the virtual cells is for the machines on which the cutting operation is done. Virtual cell configuration and machine sharing are also related to the usage of the similarity coefficient method for the parts grouping, which subsequently affects the virtual cell machine choices. This means that if the production technology changes it will affect the structure of the virtual cells in a production stage and the machine sharing between the virtual cells. 


\section{CONCLUSION}

The paper presented different production planning decisions concerning the PBC system parameters and the virtual cell formation under different design objectives. Presented method for virtual cell formation is simpler in comparison to cell formation methods proposed in [33] and [34]. Period length and stage contents definition have a big influence on virtual cells formation and reconfiguration. It is important to notice that besides the PBC system parameters, the choice of the parts grouping method can also influence the structure of the part group and the structure of the virtual cell.

In order to improve the quality of the production planning decisions, it would be interesting to compare the virtual cell formation method presented in this paper with other GT design methods (such as Classification and Coding method), and to test them (simulate) within same production system conditions and constraints. Further improvements of production schedule would also be interesting to investigate, for example by applying other known composite heuristics, and also methods such as simulated annealing [35], and comparing them with the heuristics used in this paper. Besides the resource usage optimization mentioned in the results section, the future work will also include dual resource (machines and workers) constraints for the virtual cell formation.

\section{ACKNOWLEDGEMENT}

Research for this article was conducted under the project no. TR35050 approved by Ministry of Education, Science and Technological Development of Republic of Serbia.

\section{REFERENCES}

[1] Nomden, G.; Slomp, J. (2003). The operation of virtual manufacturing cells in various physical layout situations, Proceedings of the GT/CM World Symposium, 255-260

[2] Nomden, G.; Slomp, J.; Suresh, N. C. (2005). Virtual manufacturing cells: a taxonomy of past research and identification of future research issues, International Journal of Flexible Manufacturing Systems, Vol. 17, No. 2, 71-92, doi:10.1007/s10696-006-8122-1

[3] Wang, C.; Liu, X.-B.; Zhao, G.-Z.; Chin, K. O. (2014). Multi-objective integrated production planning model and simulation constrained doubly by resources and materials, International Journal of Simulation Modelling, Vol. 13, No. 2, 243-254, doi:10.2507/IJSIMM13(2)CO10

[4] Huang, X. W.; Zhao, X. Y.; Ma, X. L. (2014). An improved genetic algorithm for job-shop scheduling problem with process sequence flexibility, International Journal of Simulation Modelling, Vol. 13, No. 4, 510-522, doi:10.2507/IJSIMM13(4)CO20

[5] Božičković, R.; Radošević, M.; Cosić, I.; Soković, M.; Rikalović, A. (2012). Integration of simulation and lean tools in effective production systems - Case study, Strojniski vestnik Journal of Mechanical Engineering, Vol. 58, No. 11, 642-652, doi:10.5545/sv-jme.2012.387

[6] Benders, J.; Riezebos, J. (2002). Period batch control: classic, not outdated, Production Planning \& Control, Vol. 13, No. 6, 497-506, doi:10.1080/09537280210162941

[7] Hyer, N. L; Brown, K. A. (1999). The discipline of real cells, Journal of Operations Management, Vol. 17, No. 5, 557-574, doi:10.1016/S0272-6963(99)00003-0

[8] Slomp, J.; Krushinsky, D.; Caprihan, R. (2011). Periodic virtual cell manufacturing (P-VCM) concept, design and operation, Proceedings of the IEEE International Conference on Industrial Engineering and Engineering Management, 337-341

[9] Balakrishnan, J.; Cheng, C. H. (2007). Multi-period planning and uncertainty issues in cellular manufacturing: a review and future directions, European Journal of Operational Research, Vol. 177, No. 1, 281-309, doi:10.1016/j.ejor.2005.08.027

[10] Drolet, J. R. (1989). Scheduling Virtual Cellular Manufacturing Systems, PhD Thesis, Purdue University, West Lafayette 
[11] Mak, K. L.; Wang, X. X. (2002). Production scheduling and cell formation for virtual cellular manufacturing systems, The International Journal of Advanced Manufacturing Technology, Vol. 20, No. 2, 144-152, doi:10.1007/s001700200136

[12] Slomp, J.; Chowdary, B. V.; Suresh, N. C. (2005). Design of virtual manufacturing cells: a mathematical programming approach, Robotics and Computer-Integrated Manufacturing, Vol. 21, No. 3, 273-288, doi:10.1016/j.rcim.2004.11.001

[13] Mahdavi, I.; Aalaei, A.; Paydar, M. M. (2011). Multi-objective cell formation and production planning in dynamic virtual cellular manufacturing systems, International Journal of Production Research, Vol. 49, No. 21, 6517-6537, doi:10.1080/00207543.2010.524902

[14] Han, W.; Wang, F.; Lv, J. (2014). Virtual cellular multi-period formation under the dynamic environment, IERI Procedia, Vol. 10, 98-104, doi:10.1016/j.ieri.2014.09.097

[15] Benders, J. (2002). The origin of period batch control (PBC), International Journal of Production Research, Vol. 40, No. 1, 1-6, doi:10.1080/00207540110069087

[16] Burbidge, J. L. (1994). The use of period batch control (PBC) in the implosive industries, Production Planning \& Control, Vol. 5, No. 1, 97-102, doi:10.1080/09537289408919475

[17] Borgen, E. (1996). Production management principles in newspaper pre-press production, Production Planning \& Control, Vol. 7, No. 1, 96-98, doi:10.1080/09537289608930329

[18] da Silva, F. M; Fernandes, F. C. F. (2008). Proposal of a production control system for shoemakers operating in a resources-to-order or make-to-order product market environment, Gestão \& Produção, Vol. 15, No. 3, 523-538, doi:10.1590/S0104-530X2008000300008

[19] Severino, M. R.; Junior, M. L.; Campanini, L.; Guimarães, A. A.; Filho, M. G.; Aguilera, M. (2010). Lead time reduction in a capital goods company by means of the implementation of period batch control system, Production (Produção), Vol. 20, No. 4, 612-625, doi:10.1590/ S0103-65132010005000030

[20] Riezebos, J. (2001). Design of a period batch control planning system for cellular manufacturing, $\mathrm{PhD}$ Thesis, University of Groningen, Groningen

[21] Zelenovic, D. M.; Tesic, Z. M. (1988). Period batch control and group technology, International Journal of Production Research, Vol. 26, No. 3, 539-552, doi:10.1080/00207548808947883

[22] Kaku, B. K.; Krajewski, L. J. (1995). Period batch control in group technology, International Journal of Production Research, Vol. 33, No. 1, 79-99, doi:10.1080/00207549508930139

[23] Rachamadugu, R.; Tu, Q. (1997). Period batch control for group technology - An improved procedure, Computers \& Industrial Engineering, Vol. 32, No. 1, 1-7, doi:10.1016/S0360$\underline{8352(96) 00054-X}$

[24] Burbidge, J. L. (1989). Production flow analysis for planning group technology, Clarendon Press, Oxford

[25] Berlec, T.; Kušar, J.; Žerovnik, J.; Starbek, M. (2014). Optimization of a product batch quantity, Strojniski vestnik - Journal of Mechanical Engineering, Vol. 60, No. 1, 35-42, doi:10.5545/svjme.2013.1009

[26] Yan, L.; Irani, S. A. (1999). Classroom tutorial on the design of a cellular manufacturing system, Irani, S. A. (Ed.), Handbook of Cellular Manufacturing Systems, John Wiley \& Sons, New York, 613-659

[27] Dijkstra, E. W. (1959). A note on two problems in connexion with graphs, Numerische Mathematik, Vol. 1, No. 1, 269-271, doi:10.1007/BF01386390

[28] Hagberg, A. A.; Schult, D. A.; Swart, P. J. (2008). Exploring network structure, dynamics, and function using NetworkX, Proceedings of the $7^{\text {th }}$ Python in Science Conference (SciPy2008), 11 15

[29] Burbidge, J. L. (1988). Operation scheduling with GT and PBC, International Journal of Production Research, Vol. 26, No. 3, 429-442, doi:10.1080/00207548808947874

[30] Gracanin, D.; Lalic, B.; Beker, I.; Lalic, D.; Buchmeister, B. (2013). Cost-time profile simulation for job shop scheduling decisions, International Journal of Simulation Modelling, Vol. 12, No. 4, 213-224, doi:10.2507/IJSIMM12(4)1.237

[31] Suzić, N.; Stevanov, B.; Ćosić, I.; Anišić, Z.; Sremčev, N. (2012). Customizing products through application of group technology: a case study of furniture manufacturing, Strojniski vestnik Journal of Mechanical Engineering, Vol. 58, No. 12, 724-731, doi:10.5545/sv-jme.2012.708 
[32] Pinedo, M. (2008). Scheduling: theory, algorithms, and systems, $3^{\text {rd }}$ edition, Springer Science+Busines Media LLC, New York

[33] Rezazadeh, H.; Mahini, R.; Zarei, M. (2011). Solving a dynamic virtual cell formation problem by linear programming embedded particle swarm optimization algorithm, Applied Soft Computing, Vol. 11, No. 3, 3160-3169, doi:10.1016/j.asoc.2010.12.018

[34] Paydar, M. M.; Saidi-Mehrabad, M. (2015). Revised multi-choice goal programming for integrated supply chain design and dynamic virtual cell formation with fuzzy parameters, International Journal of Computer Integrated Manufacturing, Vol. 28, No. 3, 251-265, doi:10.1080/0951192X.2013.874596

[35] Rathinam, B.; Govindan, K.; Neelakandan, B.; Raghavan, S. S. (2015). Rule based heuristic approach for minimizing total flow time in permutation flow shop scheduling, Technical Gazette, Vol. 22, No. 1, 25-32, doi:10.17559/TV-20130704132725 